\title{
First-Hand Experience and Second-Hand Information: \\ Changing Trust across Three Levels of Government
}

\author{
Gina Yannitell Reinhardt
}

\begin{abstract}
:
Little is known about how different sources of information drive citizen trust in government. To address that gap this paper compares disaster evacuees to observers, noting how trust differs as attention to media coverage increases. First-hand experience supplies information to update trust through biological and personal processes, and performance assessments, while secondary sources provide information about other people's experiences, filtered through lenses that take an active role in crafting information. These two types of information have varying effects depending on the level of government being trusted. Using surveys administered a year after Hurricane Katrina, I find that Katrina evacuees have the highest trust in federal government, until they start paying attention to media coverage, and that attention to coverage has the most dramatic effect on these evacuees compared to all other groups. I also find that increasing attention to second-hand information corresponds with higher trust in local officials, and that this effect decreases as the level of government increases. It appears media coverage creates a comparison in the mind of hurricane evacuees, causing them to update their performance assessments based on comparing their own experience to that which they observe, and thereby updating their political trust.
\end{abstract}

\section{Key Words:}

Political trust; government performance; media; disasters; federalism 
Extensive work shows that people base political trust on assessments of government performance, including issues such as the economy (Keele 2005; Hetherington and Rudolph 2008), scandals (Keele 2007), and crime (Kelleher and Wolak 2007; Sindall, Sturgis, and Jennings 2012). When citizens believe public officials do a poor job, trust in them tends to decline, a pattern that transcends national, state, and local levels (Rahn and Rudolph 2002). In the past decade, public management of and policy regarding disasters has also been blamed for declining political trust (Robinson et al 2013). Fournier (2010) argues that the 2010 BP oil spill caused "a crisis of faith in public and private institutions." Nicholls and Picou (2013) tie Hurricane Katrina to drops in American political trust locally, state-wide, and federally. And after the Dai-ichi nuclear disaster in March 2011, a poll revealed trust in Japanese institutions "had plummeted” (Economist 2012).

Do disasters drive political trust in ways different from non-critical events? Current studies do not distinguish disaster management from other management or policy situations. In this paper, I contribute to the literature on political trust by arguing that disasters have a unique effect on political trust based on the way information is delivered to disaster survivors versus observers. These differences do not exist in the same way in non-critical management and policy episodes, but they do mold the perception of government performance both for those experiencing a disaster, and for those observing the event from afar. As information is received, citizens update their political trust differently depending on whether they experience or observe the critical event. Differences in the source and quality of information then drive differences in political trust. Even when the media determines a disaster to be a policy or management failure, such as Hurricane Katrina, those experiencing the policy and management decisions directly can have their political trust bolstered, while those observing the decisions through media filters have their political trust damaged.

The hurricanes of the 2004-2005 hurricane seasons provide a unique opportunity to study information and trust in a federal system because they offer well-managed and poorly-managed 
disasters that were followed by observers around the world (Kohut, Allen, and Keeter 2005; Gallup 2005) and required activity from all levels of government (Schneider 2008). Using data collected on political trust and hurricane experience after these seasons, I examine the relationship between attention to media coverage, hurricane evacuation experience, and political trust at all levels of government. I find support for my propositions that disaster survivors update political trust based on first-hand experience with the outcomes of policy and management decisions, while observers rely on third-party sources that relay secondary information regarding other people's experiences. These differences in information beget differences in political trust that depend on the perception of the performance being evaluated. Importantly, those who have direct experiences with disasters end up with higher levels of political trust than observers, as long as they pay no attention to media coverage. When disaster survivors do pay attention to media coverage, however, that coverage molds political their political trust and makes it look more like that of disaster observers. Among the two mediawatching groups, local political trust increases with attention to coverage, state political trust increases at a lower rate, and federal political trust declines. That is, the effect of attention to media coverage on political trust becomes more negative, the higher the level of government.

These findings are important in the wealth of comparisons they allow us to make. Comparing the opinions of disaster observers and survivors to each other is rarely done because disaster survivors are such a difficult-to-reach population. Consequently, studies tend to either focus exclusively on survivors, generally in shelters (Eckel, Mahmoud, and Wilson 2009; Whitt and Wilson 2007), or exclusively on observers (Maestas et al 2008; Schneider 2008). Comparing media effects on trust across levels of government has been done, but never with observers and survivors side by side such that we can see how the trust of two groups moves as media and the level of government both change. The fact that the slope of the effect of attention to media coverage on political trust becomes more negative as the level of government increases speaks to the need to return to the 
ongoing debate on the sources of national and subnational trust (Uslaner 2002; Hetherington and Nugent 2001; Rahn and Rudolph 2002; Jennings 1998), which have not yet considered disaster management or media behavior as causes.

The dichotomy between survivors and observers distinguishes disasters from other management and policy outcomes that influence political trust only as they become salient to an individual (Hetherington and Husser 2011). Non-disasters condition political trust through individual experience with those issues and with their perceived outcomes (Chanley, Rudolph, and Rahn 2000; Hetherington 1998; Keele 2005, 2007; Hetherington and Rudolph 2008; Weatherford 1987). But for disaster observers, critical events form political trust through perceptions of others' experiences. This doubles the power of secondary sources, which first have the opportunity to select and mold information as it moves from the survivor experience to the observer perception, and then the ability to craft political trust for people who are not directly affected by a policy outcome.

My findings imply that media coverage of disasters has the potential to override personal disaster experience in the formation of performance assessments. This phenomenon suggests that trust is damaged not simply by personal dissatisfaction with particular policy decisions, but by evaluating one's personal circumstances in the context of other's experiences, and in light of the opinions of information conduits. These implications are particularly relevant at a time when citizens are easily categorized based on their preferred source of information. Those receiving second-hand information from Fox News and MSNBC, the least informative news sources (Cassino, Woolley, and Jenkins 2012), will trust differently from newspaper readers (Moy and Scheufele 2000). If media outlets are driven by market considerations, outlets' marketing strategies are forming political trust systematically according to viewer characteristics.

These findings also have practical implications. Trust is necessary to achieve citizen compliance that begets safety, efficiency, and cooperation (Wang and Kapucu 2008). Trust in public 
officials gives them the legitimacy and respect required to fulfill their duties (Christensen \& Lægreid 2005), including managing disasters. At critical moments, trust in disaster managers is necessary to the smooth operation of response efforts and swift economic recovery (Kapucu 2008). A loss of trust can lead to a failure to cooperate in crucial moments, such as the recent outbreak of Ebola in West Africa. The national-level CDC is directing management of the Ebola crisis for the US, and citizens are receiving their information regarding the situation from media sources of their choice. These media outlets deliver information based on the desire to hold viewers' attention, molding trust in the CDC and either bolstering or undermining the agency's ability to communicate and contain the outbreak in the process.

\section{Political Trust, Disasters, and Information}

Consider an individual-level theory of government performance and trust, where trust is an orientation toward public officials or agencies based on character and ability (Keele 2007; Miller 1974). Trust is the belief one has that public officials can and will perform their jobs: $A$ trusts $B$ to do $X$ (Hardin 2002, p. xx). Trust increases with the belief that an official is both capable of doing its job (I trust bim to do it because he is competent at doing it) and has the moral fortitude to do it when called upon (I trust him to do it even if it is a personally difficult thing to do; see Nicholls and Picou 2013; Levi and Stoker 2000; Ullmann-Margalit 2004; Hardin 2004).

Trust is grounded in part in an evaluation of officials' performance. Information to assess performance originates on one of two levels: primary or secondary. Primary, first-hand information comes from interactions with public officials and their management and policy decisions; personal experience with the outcomes of those decisions updates trust. Secondary information regards outcomes that affect other people, decisions with which an individual does not have actual experience; with secondary information, perceptions update trust. A source of information conditions political knowledge and trust, because the quality of information can deteriorate as it 
moves from primary sources to secondary delivery mechanisms (Moy and Scheufele 2000; Moy and Pfau 2000; Lin et al 2014). When perceptions gleaned from secondary sources are negative, they damage political trust much more than positive perceptions boost it, and can be nearly impossible to reverse (Weitzer 2002; Kaminski and Jefferis 1998).

Disasters, unplanned disruptions in social systems sparked by critical events (Quarantelli, Lagadec, and Boin 2006), separate citizens into two groups based on how they receive information about government performance. Those living through the disaster update political trust based on first-hand experience, which triggers mechanisms of performance assessment as well as biologicallydriven trust processes. These disaster experiencers have their political trust activated due to the uncertainty inherent in critical situations (Chryssochoidis, Strada, and Krystallis 2009), particularly when they sacrifice their personal autonomy and decision-making power to those in charge, trusting public officials to make decisions on their behalf (Montgomery, Jordens, and Little 2008). Evacuees bond with other survivors and public officials during evacuation and recovery, which can also build political trust through release of the neuropeptide oxytocin (Merolla et al 2013). In addition to these biological and personal means, evacuees update political trust with performance assessments based on their own experience.

Meanwhile, disaster observers watch from afar, receiving information via conduits such as the media, which is likely to slant their perceptions for two reasons. First, disaster coverage in the media tends to be evocative and shocking (Izard and Perkins 2011), priming viewers to receive emotional suggestion rather than fact (Atkeson and Maestas 2012). Personal interest stories result in skewed perceptions (Perkins and Li 2011; Jha and Izard 2011) and false information (Stromback and Nord 2006; Sommers et al 2006). Observers tend to forget that the information is not about their own experience with public management or policy outcomes; rather, it is information about other people's experiences. Already anxious, observers are inclined to distort perceptions when thinking about 
applying another's situation to their own circumstances (Wahlberg and Sjoberg 2000; Camerer and Kunreuther 1989; Leschine 2002).

Studies show that viewers receive shocking and visceral information as though it is "real life," rather than mediating it with "the cognitive acknowledgement that this is 'only television," (Mutz and Reeves 2005, p. 3), even though journalists have chosen to convey images and stories unrepresentative of the population of events. While media sources are responding to a 24-hour news cycle, government sources are carefully checking facts before giving information, meaning official updates come more slowly. "When more information is coming from media than from government, trust begins to shift" toward the media as a reliable source of information (Wang and Kapucu 2008). If the information differs, distrust in public officials grows.

Disaster experiencers also turn to media sources for information. For example, evacuees may turn to television news to find weather reports, or they may hunt down visual evidence of damages in the disaster area on the internet. Although this information does not originate from personal contact with public officials, it still pertains to outcomes that influence them directly. They will therefore receive it differently from the way of observers, who will be receiving information that pertains to someone else. Ultimately, disasters affect political trust by updating information individuals use to assess trust. That effect differs for experiencers versus observers because of the way the information is received. Experiencers receive information personally and biologically, while observers receive information via second-hand sources that take an active role in selecting and crafting the information itself.

\section{Considering Federalism}

The intricacies of federalism introduce another dimension into the relationship between disasters, information, and political trust. Because disasters activate trust in public officials, the disaster experience can either erode or strengthen political trust, and can even erode political trust at 
one level of government while strengthening it at another. This is possible due to the active role of the media and the ability to shift blame in a federalist system.

A successfully managed disaster validates and fortifies trust, uniting citizens with public officials to overcome fear, rally around a cause, and rebuild a community (Teets 2009). Poorlymanaged disasters diminish trust by exposing the inabilities of officials to carry out the work they were entrusted to perform (Troy 2004), often damaging trust more than a well-managed event can bolster it (Slovic 1993). "Trust is fragile. It is typically created rather slowly, but it can be destroyed in an instant" (Slovic 1999, p. 697).

Like disaster experience, the effect of media coverage on trust depends on the nature of the coverage. Positive reports increase trust, but not as noticeably as negative reports damage it (Slovic 1993). Negative coverage garners more viewership and therefore more media focus as well. Reports on national officials carry the bonus of appealing to the most viewers, so negative coverage on national officials tends to get a disproportionate amount of media attention, and therefore has disproportionate negative effects on national political trust (Littlefield and Quinette 2007).

Not all citizens know the responsibilities of each level of government during a disaster (Schneider 2008), making it easier for public officials to shift blame to other levels of government (Birkland and Waterman 2008). With the media's assistance, this shift often goes to the national level (see Maestas et al 2008). For example, millions clamor for information during catastrophes ${ }^{\mathrm{i}}$ such as Hurricane Katrina. It is easy to lose patience, and with it trust in public officials. Hurricane Katrina was noted widely as a public management failure (Nicholls and Picou 2013), during which the media "stepped outside their role of objective observer and assumed a privileged position of pointing blame toward legitimate authorities" (Littlefield and Quinette 2007, p. 27). Coverage of Katrina is thus seen as markedly damaging to trust (Birkland and Waterman 2008; Atkeson and Maestas 2012). 
In contrast, US hurricanes leading up to Katrina had largely been managed well, and are likely to have bolstered trust for those living through them. The 2004 experience with Hurricane Charley resulted in efficient responses to Florida's subsequent hurricanes of that season (Frances, Ivan, and Jeanne), including swift coordination of local, state, and federal responses (FEMA 2009). Local officials' management of these disasters meant national media coverage was less, and those who experienced these hurricanes are likely to have had good experiences.

I thus propose that when disasters occur, observers react differently from those experiencing disasters directly. In other words, reactions to disaster management are mediated by the experience of those who survived it, and by the media's portrayal of the event to those who observed it. When comparing those who live through the disaster to those who observe it, disasters thus offer us the chance to examine a unique relationship between information and trust within the citizenry. And because disaster management, and the policies surrounding it, are the responsibility of public officials at the local, state, and federal levels, this opportunity exists at all levels of government.

\section{Putting it Together: Hypotheses}

Based on the discussion above, I hypothesize three relationships:

Hypothesis 1a: The more negative the experience, measured by first-hand Katrina evacuation, the lower the trust.

Hypothesis 1b: The more positive the experience, measured by evacuation for non-Katrina hurricanes, the higher the trust.

We should see the lowest trust among those experiencing a "bad" disaster, the highest among those experiencing a "good" disaster, and moderate trust among those who observe disasters filtered through the media. Hypotheses $1 \mathrm{a}-1 \mathrm{~b}$ may seem obvious, but should be tested if only to validate the sample used here.

Hypothesis 2: The higher the level of government, the more negative the effect of attention to media coverage on trust. 
National media coverage focuses on negative aspects of critical events and national public figures (Littlefield and Quinette 2007). Regardless of evacuation experience, we should expect the most positive relationship (slope) between media and trust to be at the local level. For state trust, that relationship should be less positive, and federal trust should have the least positive relationship. Said differently, as the level of government increases the slope of the relationship between attention to media coverage and trust should grow more negative.

I examine these propositions with two different methodologies. First, a difference of means test clarifies whether Hypotheses 1-2 are worth pursuing. If the media has an influence on trust, we should see different levels of trust among citizens that pay different levels of attention to the media. The second test, a Seemingly Unrelated Regression (SUR) model, allows for cross-sectional analysis of the variation in trust with controls for individual demographics and partisanship. A SUR model is almost the equivalent of separate Ordinary Least Squares (OLS) models for federal, state, and local political trust, except the SUR model estimates all trust variables, coefficients, and standard errors of each separate OLS at the same time. This allows the simultaneous estimation of multiple dependent variables with independent variables that are shared or unique to one or more levels of trust, and accounts for the possibility of correlated error terms among the estimated equations. If there are no correlated error terms, SUR estimations will be identical to separate OLS estimations (Zellner 1962).

\section{Model, Data, and Estimation}

I test these hypotheses in the context of the 2004-2006 hurricane seasons. Containing more than 10 major hurricanes that required evacuation, these were the deadliest and costliest seasons on record, displacing over three million people, costing over $\$ 202$ billion, and killing 2150 people (Lott et al 2013; Stein et al 2011). Survey data was collected in September 2006, one year after Hurricanes Katrina and Rita. The lag between natural event and survey is important as it allows for short-term effects of the disasters to wane. We know extreme reactions are likely to abate over time (Chong and 
Druckman 2010; Bracht and Glass 1968). Fielding this study a year after the hurricanes makes it less likely to measure ephemeral phenomena and more likely to capture enduring effects.

Data is from an internet survey collected in 2006, administered by Survey Sampling International $(\mathrm{SSI})^{\mathrm{ii}}$ to residents of hurricane-threatened areas in the US. Hurricane-threatened areas contain respondents with registered addresses in a county or parish that either borders the coast or is separated from the coast by no more than one other county/parish. The region surveyed spans the US coastline from Texas through North Carolina. Displaced residents, at the time of the survey living outside their original home counties/parishes, were included based on their original physical home addresses before displacement, so responses came from 38 states and Puerto Rico. Of the 7024 respondents, $2329(33.16 \%)$ reported evacuating for a hurricane during the 2004-2006 hurricane seasons. Of those, $1068(15.21 \%)$ had still not returned home, which we take as evidence that the sampling frame was useful for contacting a difficult-to-reach population, while still striving for maximum generalizability (Online Materials contain survey questions and descriptive statistics).

There has been much debate and scholarship on the proper measurement of trust. Recall that trust is based on one's competence, or ability to perform one's job, as well as one's credibility, or believability and character (Keele 2007; Hardin 2004; Nicholls and Picou 2013). Scholars often use indices to capture the multi-dimensionality of trust. Many use the Trust in Government Index from the American National Election Studies (ANES), which offers easily accessible longitudinal data, ${ }^{\text {iii }}$ but does not allow questions about trust in specific policies or officials. We opted to create an index asking specifically about $A$ 's (the respondent's) assessment of public official $B$ (e.g., the president), with respect to $Y$, disasters. Examining trust in federal, state, and local executives and emergency managers yields six dependent trust variables, one each for the: president; governor; mayor; and federal, state, and local emergency management officials. Each ranges 0-10, 10 being highest. 
Respondents who evacuated for a hurricane at any point during the 2004-2006 hurricane seasons are given a 1 for disaster experience, 0 otherwise. Katrina evacuees receive 1 for Katrina evacuation, 0 otherwise. I choose evacuees rather than all survivors (which would also include those affected who did not evacuate), because evacuees are more likely to have had experience with their local and state officials, and/or the consequences of their policy decisions, via evacuation routes and instructions, possible shelter exposure, and relinquishing/returning to property.

Measuring exposure to the media is notoriously difficult because of memory and false reporting problems (see Mutz 2011). I thus use a self-reported measure that captures attention to media surrounding Hurricane Katrina events and recovery. Maestas et al (2008) argue that attentiveness is composed of both exposure to and engagement by media coverage, and is therefore a better measure of the reception of information than a measure of frequency (0-5, 5 highest).

I control for partisanship. Keele (2005) finds that Democrats and Republicans trust the President more when he is a member of their party, and Schmitt, Gunther, and Liebhart (2004) find observers likely to accept second-hand information fitting their partisan expectations. Since President Bush appointed the Director of FEMA and was seen with him during Katrina recovery, I expect Republicans to be more trusting of President Bush and FEMA. In state trust regressions, I control for membership in the governor's party $(0,1),{ }^{\text {iv }}$ expecting trust to increase for the governor and state emergency management agency among respondents who share their governor's party. Those who voted for George W. Bush receive a 1 in the dichotomous Voted for Bush variable, expected to be more trusting of federal officials than those who did not. Ideology is a 7-point scale with higher values indicating a stronger preference for government intervention (higher liberalism). ${ }^{\mathrm{V}}$

To avoid possible biases from omitted demographic variables, I include standard demographics of education, age, sex, and race (Hetherington 1998; Keele 2005; Christensen and Lægreid 2005). Standard expectations are that men trust less than women (Christensen and Lægreid 
2005), and that race can matter in assessing trust of some officials (Rudolph and Popp 2010), particularly in the context of Hurricane Katrina, which the media characterized as a racially-salient event (Nicholls and Picou 2013; Gomez and Wilson 2008).

I am not trying to model all influences on individual political trust. Other impressive work incorporates municipal- or community-level factors (Rahn and Rudolph 2005; Marschall and Shah 2007; Rahn et al 2009). Rather, I investigate the basic idea that first-hand information, less common at higher levels of government, allows space for the media to step in and provide information that is then used to evaluate government performance and influence trust. As such, I hope to explain a facet of individual-level trust that has not been illuminated previously.

\section{A Visual Analysis}

When hypotheses involve categorical variables, a visual inspection can be a useful intuitive test: do the measures in question appear to move according to the hypothesized relationships? If trust and attention to the media move together conditional on the level of government, it would provide nominal evidence of a relationship. Figure 2 plots political trust (averaged over all respondents) and attention paid to media coverage of Hurricane Katrina for each of the 6 officials.

The visual pattern is strikingly consistent with Hypothesis 2, that the effect of attention to media coverage will be most positive at the local level, and most negative at the federal level. The two lowest, dashed lines show trust in FEMA and the President declining with greater attention to media coverage. Trust in state and local officials appear to either go up or be unresponsive. Difference-of-means tests confirm (Table 1): those paying high attention to coverage have significantly lower federal trust, similar state trust, and significantly higher local trust than those who pay low attention. With this preliminary positive support for our second hypothesis, I move on to more complex statistical analysis. 


\section{Results}

Table 2 displays the seemingly unrelated regression (SUR) for all six officials: a respondent's president, FEMA, governor, state EMA, mayor, and local emergency services. Each model contains the variables mentioned above plus controls for state of residence prior to evacuation, using Louisiana as a baseline. The attention to media variable is entered on its own and interacted with each type of evacuation experience, to allow attention to coverage to have different effects for evacuees of Katrina, evacuees of other hurricanes, and observers.

I use Presidential Trust results to help explain the table. Katrina gives the change in trust for Katrina evacuees (compared to observers) who pay zero attention to media coverage: .81 ( $p<.01)$ for President Bush. Non-Katrina is the change in trust for evacuees of other hurricanes who pay no attention to coverage: an insignificant -.04. Attention to Media for Observers is the change in trust for a unit increase in attention to media for observers $(-.05 ; p<.05)$. If we plotted the relationship between attention and trust for observers, and did the same for Katrina evacuees, the coefficient on Katrina experience * Media gives the difference in the slopes of those two lines. For the President, attention has a negative effect for observers, and the effect is .22 more negative for Katrina evacuees $(p<.01)$. A similar interpretation is appropriate for Non-Katrina experience * Media. The effect of attention to media coverage, conditional on being a Katrina evacuee, is the sum of coefficients for Media and Katrina experience * Media (-.05-.22=-.27). The second and third rows of Table 2 give coefficients for these linear combinations. For Katrina evacuees, a one-unit attention increase lowers trust in President Bush by $.27(p<.01)$. Attention for evacuees of other hurricanes is insignificant. ${ }^{\text {vi }}$

Consider Hypotheses 1a-b, which assess the disaster experience as negative or positive by whether a respondent evacuated for Katrina or a non-Katrina hurricane. These hypotheses are borne out under certain conditions. The poor (Katrina) disaster experience has created lower levels of trust at the federal level, but only among Katrina evacuees who pay attention to media coverage. Katrina 
evacuees who pay no attention to the media trust President Bush .81 more, and FEMA .91 more, than observers (both $p<.01$ ), and exhibit no differences from observers at all in state or local trust. Meanwhile evacuees of other hurricanes have a higher trust than observers of their local Mayor and Local EMA (both .32 higher; $p<.05$ and $p<.01$ ). Unexpectedly, however, those non-Katrina evacuees who pay no attention to the media actually trust FEMA less than observers (.32 points lower, $p<.01)$.

Turn now to Hypothesis 2, which posits that increasingly negative attention and increasing focus on higher levels of government will cause the slope of the relationship between attention to media and trust to decrease as the level of government increases. The results for Hurricane Katrina evacuees, given in the second row of Table 2 , most vividly bear out this prediction. Local trust and attention have a significantly positive slope (.14 Mayor, .22 Local EMA; both $p<.01)$, flatten at the state level (insignificant .06 and .00 ), and then move to a significantly negative slope for federal trust (-.27 President, -.36 FEMA; both $p<.01)$. For observers (first row) the slope pattern is the same: the highest slope is for local trust (.21 Mayor, .19 Local EMA; both $p<.01)$, slope declines but remains significant for state trust (.12 Governor, .15 State EMA; both $p<.01)$, and then is lowest for federal trust (-.05, $p<.05$ President; -.08, $p<.01$ FEMA). Evacuees of non-Katrina hurricanes differ. Attention to media has no effect on federal trust, but reflects increases in trust by similar amounts for the Governor, State EMA, Mayor, and Local EMA (.16, .14, .16, .16; all $p<.01)$.

Partisanship variables are significant in particular regressions. Democrats have lower trust than Independents in President Bush (.75), FEMA (.36), and the Governor (.21; all $p<.01)$. Republicans have higher trust in President Bush (1.29, $p<.01)$, FEMA (.68, $p<.01)$, State EMA (.21, $p<.01)$, the Mayor $(.52, p<.01)$, and Local EMA $(.42, p<.01)$. Sharing the Governor's party increases trust in the Governor $(1.07, p<.01)$, all but two of whom were Republican, and State EMA (.23, $p<.01)$. Voting for President Bush has a positive link with trust for all officials, with the largest coefficient unsurprisingly going to President Bush himself. 
Previous theories and findings suggest that skepticism, possibly stemming from experience, education and an urge to challenge authority, will have lower political trust (Fiscella, Franks, and Clancy 1998; Catterberg and Moreno 2005). Negative relationships between trust and sex, age, education, and employment confirm these ideas. It is also not surprising that Blacks are significantly less trusting of their Local EMA than respondents of other races $(-.56, p<.01),{ }^{\mathrm{vii}}$ or that men are less trusting than women of FEMA, Governors, State EMA, and Mayors (-.22, -.15, -.15, -.18, all $p<.05)$.

\section{Discussion}

The idea that the media influences political trust is not new. What is new is the ability to compare these influences between people who experience a critical event and those who observe the event only through media coverage. The opportunity to gauge the trust of disaster evacuees who paid no attention to coverage reveals that experience with what scholars and journalists consider a policy and management failure can still boost political trust when unbiased by media coverage.

As soon as Katrina evacuees begin paying attention to media coverage, that coverage causes their trust in federal officials to slope downward much more quickly than for either of the other two groups. Why is attention to media coverage exhibiting such a drastic relationship with this group, and not either of the others? We may be witnessing a bit of distrust bred from comparison. For example, it has been noted that some evacuees were allowed to live near their abandoned homes while others were transported across state lines without being notified (Sterett 2011). If one were far from home and not paying attention to media coverage, political trust could still be intact. Upon seeing coverage of other people living near home, however, trust could drop. In other words, Katrina evacuees' trust was affected by witnessing other survivors enjoying different benefits.

It is also possible that those paying attention to the media were doing so because they did not trust their officials to manage the mitigation and recovery process appropriately, that they were predisposed to be less trusting. This point calls into question the direction of causality between trust 
and attention to media coverage. Because we do not have measures of previous trust levels, or instruments of attention to coverage, the question cannot be empirically settled here. Instead we can discuss associations between attention to coverage and trust found here, and base conclusions of causality only on theoretical guidance and previous scholarship.

Can we be certain evacuees are distinguishing the policy and management decisions according to the officials who made them? We cannot (though see Schneider 2008). Vallone, Ross, and Lepper (1985) suggest that evacuees could be using the information they receive to support ideological positions they already hold; that is, if they previously found their local officials more trustworthy than their federal officials, updates to performance assessments will be likely to confirm those preconceptions. This could be why evacuees in Sterett's (2011) study lost faith in their federal officials for evacuating them to Denver from Louisiana, despite the fact that the very need to leave Louisiana meant their state and local officials had failed to competently prepare for and mitigate the critical event. One of the finer implications of this study, then, is that we should probe more deeply into how evacuees, as a special and separate group, interact with attention to media coverage to attribute blame and update trust.

We should also be careful to note the effects of good and bad experience on trust. Those with a "good" evacuation experience (non-Katrina hurricanes) trust their local officials more than everyone else, no matter how much attention they pay to coverage of Hurricane Katrina. It is possible that another comparison effect is taking place. Del Pino (2005) reports that citizens evaluate public administration according to the results they see, meaning reports of poor performance in New Orleans could have called to mind the good performance of local officials for these other evacuees, who Trainor and Barsky (2010) tell us are the norm.

At least two more caveats must be issued. First, the sample is voluntary, and though we took steps to minimize non-responses, participation was restricted to people with access to the internet 
before the hurricanes. Yet the sample does represent a broad cross-section of people, and importantly, it does not need to be generalizable to the entire US. It would be inappropriate to target a population with a higher proportion of individuals who had no interest in or experience with hurricanes. This work should still allow generalizations about assessments and trust, based on observed versus experienced events, among observant individuals.

Second, limitations of the survey instrument prohibit examining some interesting aspects. We do not know how much information respondents received from other secondary sources, such as friends or coworkers, how often evacuees interacted with public officials, or whether respondents believe government failed. This information would give us a fuller picture of the relationships investigated here. But their absence does not destroy our inferences, because confirmed perceptions of failure are not necessary to test our hypotheses. Establishing that trust varies according to and conditional on information points us firmly toward further exploration.

\section{Conclusion}

Although previous studies have evaluated Hurricane Katrina's effects on national attributions of blame (Birkland and Waterman 2008; Maestas et al 2008; Gomez and Wilson 2008), to date no one has been able to compare a large sample of observers to evacuees to see whether and how different experiences and levels of information condition trust at various levels of government. These findings imply that the media's part in crafting trust goes beyond reporting on public officials. Even coverage about national government behavior in another part of the country, reports of state governments that are not one's own, and coverage about local governments far from one's residence can damage or bolster trust in one's officials at home. This means public officials are fighting performance issues at home, and performance perception issues caused by officials elsewhere. Considering the widespread coverage of scandals of mayors, attorneys general, and Members of 
Congress, this widespread effect of one official's news on another's trust gives new meaning to the idea that one bad story can give everyone a bad name.

While previous studies of media and attributing blame during Katrina have focused on prominent national news outlets such as The New York Times, many people get their news today from more targeted, and less informative, sources (Cassino, Wooley, and Jenkins 2012). The segmenting of media consumption into predictable groups, and the resultant targeting of media toward those groups, implies that future media coverage will shape trust in different ways for different observers. As these groups continue to use second-hand information to shape their performance assessments, trust will depend on the media outlet and the public official in question much more than it has in the past, making differences in information delivery all the more crucial to understand.

Determining the impetus of political trust is essential in a federal system, where power and responsibility are distributed across levels of government. The task is particularly important during critical times because decisions happen quickly and policies must be followed swiftly, often without time to deliberate alternative courses of action, and often by officials in bureaucratic agencies. Agency and organization theories tell us these managers are appointed so someone with expertise will be in charge of managing specific policy arenas (McCubbins, Noll, and Weingast 1987; 1989), in this case emergencies and disasters. What we must remember is that the managers in these agencies are not susceptible to electoral review. We therefore have to trust that they are competent and believable; otherwise we have no reason to presume they can or will accomplish the tasks associated with their jobs. Trust is the bond that gives citizens confidence operations will go well during a disaster, and thereby gives public officials the space to make the decisions necessary to achieve success. For the decision makers appointed to make policy and manage crises, political trust is necessary to do their jobs. If we want to manage the emergencies, we have to trust the managers. 
${ }^{\mathrm{i}}$ A catastrophe is worse than a disaster in that it damages multiple communities, and emergency personnel cannot perform their functions due to death, injury, or inability to reach those in need. Most activities stop, including worship, recreation, and public services (Quarantelli 2006).

ii SSI fielded a random sample within the target population. We restrictively defined nonresponses as "unknown eligibility" they might indicate unwillingness, unavailability, or death. By this estimate, our response rate was AAPOR-1 9.4\% (Smith 2009). As Merkle and Edelman (2002) and Keeter et al (2006) find no connection between response rate and survey accuracy, the rate here is not a concern. iii The ANES is collected biennially during even-numbered years. Derived from Stokes (1962), the questions were designed to gauge "basic evaluative orientations toward the national government," (p. 64). Stokes never mentions political trust or trust in government in his original analysis.

iv This is collinear with Republican when the governor is Republican. I retain the basic party control because, as Keele (2005) points out, there may be differences in trust due to party identification.

${ }^{\vee}$ Erikson, MacKuen, and Stimson (2002) find that people mislabel their ideology, e.g. calling themselves liberal when opposing intervention. I follow Keele (2005) and measure ideology through support for government economic intervention. Higher support indicates more liberal preferences.

${ }^{v i}$ These values were generated with Stata's post-estimation lincom command. If B is the vector of coefficients, $\mathrm{V}$ is the covariance matrix of $\mathrm{B}$, and $A=A^{T} * \mathrm{~B}$ is a vector defining the linear combination, the variance of the linear combination is $A^{T} * \mathrm{~V} * \mathrm{~A}$ (Judge et al 1985).

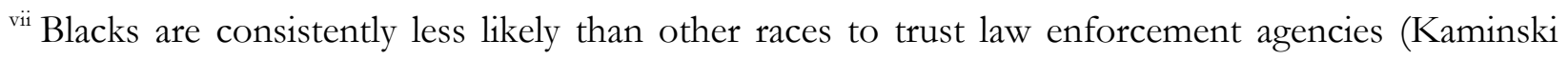
and Jefferis 1998; Sindall, Sturgis, and Jennings 2012; Weitzer 2002). 


\section{References}

Atkeson, Lonna Rae, and Cherie D. Maestas. 2012. Catastrophe Politics: How Extraordinary Events Redefine Public Perceptions of Government. Cambridge, UK: Cambridge University Press.

Birkland, Thomas, and Sarah Waterman. 2008. "Is Federalism the Reason for Policy Failure in Hurricane Katrina?" Publius: The Journal of Federalism 38(4): 692-714.

Bracht, Glenn H., and Gene V. Glass. 1968. “The External Validity of Experiments.” American Educational Research Journal 5 (4): 437-74.

Camerer, Colin F., and Howard Kunreuther. 1989. "Decision processes for low probability events: Policy implications." Journal of Policy Analysis and Management 8(4): 565-592.

Cassino, Dan, Peter Woolley, and Krista Jenkins. 2012. "What You Know Depends on What You Watch: Current Events Knowledge Across Popular News Sources." May 3. Public Mind Poll, Fairleigh Dickinson University. http://publicmind.fdu.edu/2012/confirmed/final.pdf.

Catterberg, Gabriela and Alejandro Moreno. 2005. "The individual bases of political trust: Trends in new and established democracies." International Journal of Public Opinion Research 18(1): 31-48.

Chanley, Virginia A., Thomas J. Rudolph, and Wendy M. Rahn. 2000. "The Origins and Consequences of Public Trust in Government: A Time Series Analysis." Public Opinion Quarterly 64(3): 239-256.

Chong, Dennis, and James N. Druckman. 2010. "Dynamic Public Opinion: Communication Effects over Time." American Political Science Review 104 (4): 663-80.

Christensen, Tom and Per Lægreid. 2005. "Trust in Government: The Relative Importance of Service Satisfaction, Political Factors, and Demography.” Public Performance \& Management Review 28 (4): 487-511.

Chryssochoidis, George, Anna Strada and Athanasios Krystallis. 2009. "Public Trust in Institutions and Information Sources Regarding Risk Management and Communication: Towards 
Integrating Extant Knowledge." Journal of Risk Research 12 (2): 137-185.

Del Pino, Eloísa. 2005. "Attitudes, Performance, and Institutions: Spanish Citizens and Public Administration." Public Performance \& Management Review 28(4): 512-531.

Eckel, Catherine C., Mahmoud A. El-Gamal and Rick K. Wilson. 2009. "Risk loving after the storm: A Bayesian-Network study of Hurricane Katrina evacuees." Journal of Economic Behavior \& Organization 69: 110-124.

Economist. 2012. "Trust in Government: Big Government and the Narcissism of Small Differences." The Economist. March 27. www.economist.com/blogs/democracyinamerica/2012/03/trust-government/print.

Erikson, Robert S., Michael B. MacKuen, and James A. Stimson. 2002. The Macro Polity. New York: Cambridge University Press.

Federal Emergency Management Agency. 2009. "'Charley Command:' The Beginning of a Unified FEMA-State Team. October 10. http://floridadisaster.org/hurricanes/2004/documents/ Unified \%20Command\%20Backgrounder.pdf

Fournier, Ron. "Government Fails Latest Test of Trust in Gulf." June 7, 2010.

Fiscella, Kevin, Peter Franks, and Carolyn M. Clancy. 1998. "Skepticism toward medical care and health care utilization." Medical Care 36(2): 180-189.

Gallup. "Hurricane Katrina and New Orleans/Race." The Roper Center for Public Opinion Research, 2005.

Gomez, Brad T., and J. Matthew Wilson. 2008. "Political Sophistication and Attributions of Blame in the Wake of Hurricane Katrina." Journal of Federalism 38 (4): 633-50.

Hardin, Russell. 2002. Trust and Trustworthiness. New York: Russell Sage Foundation.

Hardin, Russell. 2004. “Distrust: Manifestations and Management.” In Russell Hardin, edited by Distrust. New York: Russell Sage Foundation: 3-33. 
Hetherington, Marc J. 1998. "The Political Relevance of Political Trust." American Political Science Review 92 (4): 791-808.

Hetherington, Marc J., and Jason A. Husser. 2011. "How Trust Matters: The Changing Political Relevance of Political Trust." American Journal of Political Science 56(2): 312-325.

Hetherington, Marc J., and John D. Nugent. "Explaining Public Support for Devolution: The Role of Political Trust." In What Is It About Government That Americans edited by John R. Hibbing and Elizabeth Theiss-Norse. 134-51. Cambridge: Cambridge University Press, 2011.

Hetherington, Marc J., and Thomas J. Rudolph. 2008. "Priming, Performance, and the Dynamics of Political Trust." The Journal of Politics 70(2): 498-512.

Izard, Ralph S., and Jay Perkins. "In the Wake of Disaster: Lessons Learned." In Lessons from Ground Zero: Media Response to Terror, edited by Ralph S. Izard and Jay Perkins. 1-14. New Brunswick, NJ: Transaction Publishers, 2011.

Jennings, M. Kent. 1998. "Political Trust and the Roots of Devolution." In Trust and Governance, ed by Valerie Braithwaite \& Margaret Levi, 218-244. New York, NY: Russell Sage Foundation. Jha, Sonora, and Ralph S. Izard. 2011. "Sources: No Time for the Rolodex." In Lessons from Ground Zero: Media Response to Terror, edited by Ralph S. Izard and Jay Perkins, 79-84. New Brunswick, NJ: Transaction Publishers.

Judge, George G., William E. Griffiths, R. Carter Hill, Helmut Lütkepohl, and Tsoung-Chao Lee. 1985. The Theory and Practice of Econometrics. 2d ed. New York: Wiley.

Kapucu, Naim. 2008. "Collaborative emergency management: better community organising, better public preparedness and response." Disasters 32(2): 239-262.

Kaminski, Robert J., and Eric S. Jefferis. 1998. "The Effect of a Violent Televised Arrest on Public Perceptions of the Police." Policing 21: 683- 706. 
Keele, Luke. 2005. "The Authorities Really Do Matter: Party Control and Trust in Government." The Journal of Politics 67: 873-86.

Keele, Luke. 2007. "Social Capital and the Dynamics of Trust in Government." American Journal of Political Science 51(2): 241-254.

Keeter, Scott, Courtney Kennedy, Michael Dimock, Jonathan Best, and Peyton Craighill. 2006. "Gauging the Impact of Growing Nonresponse on Estimates from a National RDD Telephone Survey." Public Opinion Quarterly 70(5): 759-779.

Kelleher, Christine, and Jennifer Wolak. 2007. "Explaining Public Confidence in the Branches of State Government." Political Research Quarterly 60: 707-721.

Kohut, Andrew, Jodie T. Allen, \& Scott Keeter. 2005. ‘What Was and Wasn’t on the Public’s Mind and How Opinions Changed During 2005.” Pew Research Center.

Leschine, Thomas M. 2002. "Oil spills and the social amplification and attenuation of risk." Spill Science \& Technology Bulletin 7(1): 63-73.

Levi, Margaret, and Laura Stoker. 2000. "Political Trust and Trustworthiness." Annual Review of Political Science 3: 475-507.

Lin, Chih-Chun, et al. 2014. "Evacuees' information sources and reentry decision making in the aftermath of Hurricane Ike." Natural Hazards 70(1): 865-882.

Littlefield, Robert S., and Andrea M. Quenette. 2007. "Crisis leadership and Hurricane Katrina: The portrayal of authority by the media in natural disasters." Journal of Applied Communication Research 35(1): 26-47.

Lott, Neal, Adam Smith, Tamara Houston, Karsten Shein and Jake Crouch. 2013. "Billion-Dollar U.S. Weather/Climate Disasters 1980-2012." National Oceanic and Atmospheric Administration. Maestas, Cherie D., Lonna Rae Atkeson, Thomas Croom, and Lisa A. Bryant. 2008. "Shifting the Blame: Federalism, Media, and Public Assignment of Blame following Hurricane Katrina." 
Publius: The Journal of Federalism 38(4): 609-632.

Marschall, Melissa, and Paru R. Shah. 2007. 'The Attitudinal Effects of Minority Incorporation: Examining Racial Dimensions of Trust in Urban America."UrbanAffairs Review42(5):629-658.

McCubbins, Mathew D., Roger G. Noll, and Barry R. Weingast. "Administrative procedures as instruments of political control." Journal of Law, Economics, \& Organization 3.2 (1987): 243-277.

McCubbins, Matthew D., Roger G. Noll, and Barry R. Weingast. "Structure and process, politics and policy: Administrative arrangements and the political control of agencies." Virginia Law Review (1989): 431-482.

Merkle, Daniel, and Murray Edelman. 2002. "Nonresponse in Exit Polls: A Comprehensive Analysis." In Survey Nonresponse, edited by Robert M. Groves, Don A. Dillman, John L. Eltinge, and Roderick J. A. Little, 243-58. New York, NY: John Wiley.

Merolla, Jennifer L., Guy Burnett, Kenneth Pyle, Sheila Ahmadi, and Paul J. Zak. 2013. “'Oxytocin and the biological basis for interpersonal and political trust." Political Behavior 35(4): 753-776.

Miller, Arthur H. 1974. "Political Issues and Trust in Government: 1964-1970." American Political Science Review 68 (3): 951-72.

Montgomery, Kathleen, Christopher F.C. Jordens and Miles Little. 2008. "How Vulnerability and Trust Interact During Extreme Events." Administration and Society 40(6): 621-644.

Moy, Patricia, and Michael Pfau. 2000. With malice toward all?: The media and public confidence in democratic institutions. Greenwood Publishing Group, 2000.

Moy, Patricia, and Dietram A. Scheufele. 2000. "Media effects on political and social trust." Journalism \& Mass Communication Quarterly 77(4): 744-759.

Mutz, Diana C. 2011. Population-Based Survey Experiments. Princeton: Princeton University Press. Mutz, Diana C. and Byron Reeves. "The New Videomalaise: Effects of Televised Incivility on Political Trust ". American Journal of Political Science 99(1): 1-15. 
Nicholls, Keith, and J. Steven Picou. 2013. "The Impact of Hurricane Katrina on Trust in Government." Social Science Quarterly 94(2): 344-361.

Perkins, Jay, and Xigen Li. 2011. "Cruising on Autopilot: How the Media Covered 9/11." In Lessons from Ground Zero: Media Response to Terror, edited by Ralph S. Izard and Jay Perkins, 33-50. New Brunswick, NJ: Transaction Publishers.

Quarantelli, E. L. 2006. "Catastrophes are Different from Disasters: Some Implications for Crisis Planning and Managing Drawn from Katrina." June 11. Social Science Research Council. http:/ / forums.ssrc.org/understandingkatrina/catastrophes-are-different-from-disasterssome-implications-for-crisis-planning-and-managing-drawn-from-katrina/.

Quarantelli, E.L., Patrick Lagadec, and Arjen Boin. 2006. "A Heuristic Approach to Future Disasters and Crises: New, Old and In-Between Types." In Handbook of Disaster Research, edited by Havidán Rodríguez, Enrico L. Quarantelli and Russell R. Dynes, 16-41. New York: Springer.

Rahn, Wendy, \& Thomas Rudolph. 2002. "Trust in Local Governments." In Understanding Public Opinion, 2d ed., ed by Barbara Norrander \& Clyde Wilcox, 281-300. Washington, DC: CQ.

Rahn, Wendy M., and Thomas J. Rudolph. 2005. "A Tale of Political Trust in American Cities.” Public Opinion Quarterly 69 (4): 530-60.

Rahn, Wendy M., Kwang Suk Yoon, Michael Garet, Steven Lipson and Katherine Loflin. 2009. “Geographies of Trust.” American Behavioral Scientist 52 (12): 1646-1663.

Robinson, Scott E., Xinsheng Liu, James W. Stoutenborough, and Arnold Vedlitz. 2013. "Explaining Popular Trust in the Department of Homeland Security." Journal of Public Administration Research and Theory 23(3): 713-733.

Rudolph, Thomas J., and Elizabeth Popp. 2010. "Race, Environment, and Interracial Trust.” Journal of Politics 72 (1): 74-89.

Schneider, Saundra. 2008. "Who's to Blame? (Mis) perceptions of the Intergovernmental Response 
to Disasters." Publius: The Journal of Federalism 38 (4): 715-738.

Sindall, Katy, Patrick Sturgis, and Will Jennings. 2012. "Public Confidence in the Police." British Journal of Criminology 52: 744-764.

Schmitt, Kathleen M., Albert C. Gunther, and Janice L. Liebhart. 2004. "Why Partisans See Mass Media as Biased." Communication Research 31: 623-641.

Slovic, Paul. 1993. "Perceived Risk, Trust, and Democracy." Risk Analysis 13 (6): 675-682.

Slovic, Paul. 1999. "Trust, emotion, sex, politics, and science: Surveying the risk-assessment battlefield." Risk Analysis, (19)4: 689-701.

Smith, Tom W. 2009. "A Revised Review of Methods to Estimate the Status of Cases with Unknown Eligibility." August. Chicago: U of Chicago, National Opinion Research Center.

Sommers, Samuel R., Evan P. Apfelbaum, Kristin N. Dukes, Negin Toosi and Elsie J. Wang. 2006.

"Race and Media Coverage of Hurricane Katrina: Analysis, Implications, and Future Research Questions." Analyses of Social Issues and Public Policy 6 (1): 1-17.

Stein, Robert M., Leonardo Duenas-Osorio, Birnur Buzcu-Guven, Devika Subramanian, and David Kahle. 2011. "How Risk Perceptions Influence Evacuations From Hurricanes." James A. Baker III. Institute for Public Policy, Rice University.

Sterett, Susan M. 2011. "Need and citizenship after disaster." Natural Hazards Review 13(3): 233-245.

Stokes, Donald E. 1962. "Popular Evaluations of Government: An Empirical Assessment.” In Ethics and Bigness: Scientific, Academic, Religious, Political, and Military, edited by Harlan Cleveland and Harold D. Lasswell. New York: Harper and Brothers.

Stromback, Jesper, and Lars W. Nord. 2006. "Do Politicians Lead the Tango? A Study of the Relationship between Swedish Journalists and their Political Sources in the Context of Election Campaigns.” European Journal of Communication 21 (2): 147-64.

Teets, Jessica C. 2009. "Post-Earthquake Relief and Reconstruction Efforts: The Emergence of Civil 
Society in China." China Quarterly 198: 300-347.

Trainor, Joseph E., and Lauren E. Barsky. 2010. "Reporting for Duty? A Synthesis of Research on

Role Conflict, Strain and Abandonment among Emergency Responders during Disasters and Catastrophes.” Disaster Research Center.

Troy, Patrick. 2004. "Distrust and the Development of Urban Regulations." In Distrust, edited by Russell Hardin. New York, NY: Russell Sage Foundation, 207-232.

Ullmann-Margalit, Edna. 2004. “Trust, Distrust, and In Between.” In Distrust, edited by Russell Hardin. New York: Russell Sage Foundation, 60-82.

Ulsaner, Eric M. The Moral Foundations of Trust. Cambridge: Cambridge University Press, 2002.

Vallone, Robert P., Lee Ross, and Mark R. Lepper. 1985. "The Hostile Media Phenomenon: Biased Perception and Perceptions of Media Bias in Coverage of the Beirut Massacre." Journal of Personality and Social Psychology 49(3): 577-385.

Wåhlberg, Anders AF, and Lennart Sjöberg. 2000. "Risk perception and the media." Journal of Risk Research 3(1): 31-50.

Wang, XiaoHu, and Naim Kapucu. 2008. "Public Complacency under Repeated Emergency Threats: Some Empirical Evidence." Journal of Public Administration Research and Theory 18 (1): 57-78.

Weatherford, M. Stephen. 1987. “How Does Government Performance Influence Political Support?" Political Behavior 9 (1): 5-28.

Weitzer, Ronald. 2002. "Incidents of Police Misconduct and Public Opinion." Journal of Criminal Justice 30: 397-408.

Whitt, Sam and Rick K. Wilson. 2007. "Public Goods in the Field: Katrina Evacuees in Houston." Southern Economic Journal 74(2): 377-387.

Zellner, Arnold. 1962. "An Efficient Method of Estimating Seemingly Unrelated Regressions and Tests for Aggregation Bias." Journal of the American Statistical Association 57: 348-368. 
Figure 1: Trust Target Profiles by Media Attention

Trust Target Profiles

According to Media Attention

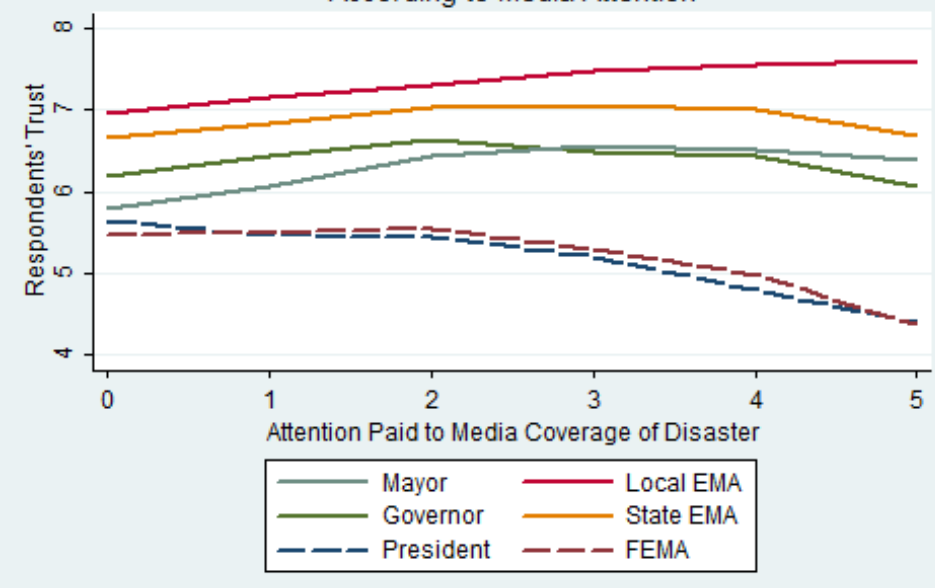




\begin{tabular}{lcccccc} 
& \multicolumn{3}{c}{ Table 1 Mean Differences of Trust in Government } \\
\cline { 2 - 6 } & \multicolumn{2}{c}{ Federal } & \multicolumn{2}{c}{ State } & \multicolumn{2}{c}{ Local } \\
\hline \multirow{2}{*}{ High Attention to Media } & President & FEMA & Governor & State & Mayor & Local \\
Low Attention to Media & 4.19 & 4.10 & 5.88 & 6.52 & 6.29 & 7.55 \\
Difference & 5.66 & 5.46 & 6.13 & 6.63 & 5.73 & 6.90 \\
$\mathrm{~N}$ & $1.46^{* *}$ & $1.35^{* *}$ & $0.26 *$ & 0.11 & $-0.56^{* *}$ & $-0.65^{* *}$ \\
\hline \hline
\end{tabular}

Note: Two-tailed tests. Comparison of means between 11-point trust indicators. ${ }^{* *} p<0.01, * p<0.05$

1 "Other Hurricanes" refer to hurricanes in the 2004-2006 seasons other than Katrina, such as Charley, Dennis, Frances, Rita, or Wilma. See Appendix A for details. 
Table 2 Estimates of Political Trust in Executives and Emergency Management Agencies at Three Levels of Government

\begin{tabular}{|c|c|c|c|c|c|c|}
\hline & President & FEMA & Governor & State EMA & Mayor & Local EMA \\
\hline Attention to Media & $-0.05 *$ & $-0.08 * *$ & $0.12 * *$ & $0.15^{* *}$ & $0.21 * *$ & $0.19 * *$ \\
\hline for Observers & $(0.02)$ & $(0.02)$ & $(0.02)$ & $(0.02)$ & $(0.02)$ & $(0.02)$ \\
\hline Attention to Media & $-0.27 * *$ & $-0.36 * *$ & 0.06 & 0.00 & $0.14^{* *}$ & $0.22 * *$ \\
\hline for Katrina Evacuees & $(0.07)$ & $(0.07)$ & $(0.06)$ & $(0.06)$ & $(0.06)$ & $(0.05)$ \\
\hline Attention to Media & -0.06 & -0.03 & $0.16^{* *}$ & $0.14 * *$ & $0.16^{* *}$ & $0.16^{* *}$ \\
\hline for non-Katrina Evacuees & $(0.04)$ & $(0.04)$ & $(0.04)$ & $(0.03)$ & $(0.04)$ & $(0.03)$ \\
\hline \multirow[t]{2}{*}{ Katrina Experience } & $0.81 * *$ & $0.91 * *$ & 0.01 & 0.20 & -0.30 & -0.13 \\
\hline & $(0.30)$ & $(0.32)$ & $(0.28)$ & $(0.24)$ & $(0.28)$ & $(0.21)$ \\
\hline \multirow[t]{2}{*}{ Katrina Experience $*$ Media } & $-0.22 * *$ & $-0.28 * *$ & -0.04 & $-0.13 *$ & -0.08 & 0.03 \\
\hline & $(0.07)$ & $(0.07)$ & $(0.07)$ & $(0.06)$ & $(0.07)$ & $(0.05)$ \\
\hline \multirow[t]{2}{*}{ Non-Katrina Experience } & -0.04 & $-0.32 *$ & -0.14 & -0.03 & $0.32 *$ & $0.32 * *$ \\
\hline & $(0.15)$ & $(0.16)$ & $(0.14)$ & $(0.12)$ & $(0.14)$ & $(0.11)$ \\
\hline \multirow[t]{2}{*}{ Non-Katrina Experience * Media } & -0.01 & 0.05 & 0.05 & -0.00 & -0.06 & -0.02 \\
\hline & $(0.05)$ & $(0.05)$ & $(0.04)$ & $(0.04)$ & $(0.04)$ & $(0.03)$ \\
\hline \multirow[t]{2}{*}{ Democrat } & $-0.75 * *$ & $-0.36 * *$ & $-0.21 * *$ & 0.04 & 0.03 & 0.03 \\
\hline & $(0.08)$ & $(0.08)$ & $(0.08)$ & $(0.07)$ & $(0.08)$ & $(0.06)$ \\
\hline \multirow[t]{2}{*}{ Republican } & $1.29 * *$ & $0.68 * *$ & $-0.25 *$ & $0.21 *$ & $0.52 * *$ & $0.42 * *$ \\
\hline & $(0.09)$ & $(0.09)$ & $(0.11)$ & $(0.09)$ & $(0.08)$ & $(0.06)$ \\
\hline \multirow[t]{2}{*}{ Governor of Same Party } & & & $1.07 * *$ & $0.23 * *$ & & \\
\hline & & & $(0.09)$ & $(0.08)$ & & \\
\hline \multirow[t]{2}{*}{ Voted for Pres. Bush } & $2.20 * *$ & $0.56 * *$ & $0.78^{* *}$ & $0.57 * *$ & $-0.18^{* *}$ & -0.06 \\
\hline & $(0.07)$ & $(0.07)$ & $(0.08)$ & $(0.07)$ & $(0.06)$ & $(0.04)$ \\
\hline \multirow[t]{2}{*}{ Ideology } & $-0.07 * *$ & 0.02 & -0.01 & -0.01 & -0.01 & $-0.04 * *$ \\
\hline & $(0.02)$ & $(0.02)$ & $(0.02)$ & $(0.02)$ & $(0.02)$ & $(0.01)$ \\
\hline \multirow[t]{2}{*}{ Race } & -0.13 & 0.13 & 0.07 & -0.17 & -0.01 & $-0.56 * *$ \\
\hline & $(0.12)$ & $(0.13)$ & $(0.11)$ & $(0.10)$ & $(0.11)$ & $(0.09)$ \\
\hline \multirow[t]{2}{*}{ Sex } & -0.12 & $-0.22 * *$ & $-0.15 *$ & $-0.15^{*}$ & $-0.18 *$ & -0.03 \\
\hline & $(0.08)$ & $(0.08)$ & $(0.07)$ & $(0.06)$ & $(0.07)$ & $(0.06)$ \\
\hline \multirow[t]{2}{*}{ Age } & $-0.01 * *$ & $-0.03 * *$ & -0.00 & $-0.01 * *$ & -0.00 & $0.01 * *$ \\
\hline & $(0.00)$ & $(0.00)$ & $(0.00)$ & $(0.00)$ & $(0.00)$ & $(0.00)$ \\
\hline \multirow[t]{2}{*}{ Education } & $-0.65^{* *}$ & $-0.58 * *$ & $-0.34 * *$ & $-0.24 * *$ & -0.06 & -0.07 \\
\hline & $(0.07)$ & $(0.07)$ & $(0.06)$ & $(0.06)$ & $(0.06)$ & $(0.05)$ \\
\hline \multirow[t]{2}{*}{ Employment } & $-0.23 * *$ & $-0.16^{*}$ & $-0.23 * *$ & -0.09 & -0.02 & 0.02 \\
\hline & $(0.06)$ & $(0.07)$ & $(0.06)$ & $(0.05)$ & $(0.06)$ & $(0.05)$ \\
\hline State Controls & Yes & Yes & Yes & Yes & Yes & Yes \\
\hline \multirow[t]{2}{*}{ Constant } & $4.39 * *$ & $4.95^{* *}$ & $3.47 * *$ & $5.10 * *$ & $4.80 * *$ & $5.91 * *$ \\
\hline & $(0.19)$ & $(0.20)$ & $(0.18)$ & $(0.16)$ & $(0.18)$ & $(0.14)$ \\
\hline Observations & 7,016 & 7,016 & 7,016 & 7,016 & 7,016 & 7,016 \\
\hline R-squared & 0.35 & 0.13 & 0.19 & 0.12 & 0.05 & 0.06 \\
\hline
\end{tabular}

Notes: Base comparison group for Democrats and Republicans is Independents. Base comparison for state controls is Louisiana. Robust standard errors in parentheses. ${ }^{* *} \mathrm{p}<0.01,{ }^{*} \mathrm{p}<0.05$ 